\title{
Some Observations on Hydrated Monocalcium Aluminate and Monostrontium Aluminate
}

\author{
Elmer T. Carlson
}

\begin{abstract}
Monocalcium aluminate hydrate, probably having the composition $\mathrm{CaO} \cdot \mathrm{Al}_{2} \mathrm{O}_{3} \cdot 10 \mathrm{H}_{2} \mathrm{O}$, was prepared by precipitation from calcium aluminate solutions at $1^{\circ} \mathrm{C}$, and by hydration of pastes of monocalcium aluminate or aluminous cement. It was obtained as hexagonal prisms, very weakly birefringent, with mean index 1.471. Three molecules of water were expelled by drying over $\mathrm{CaCl}_{2}$, without apparent change in crystal structure; however, the structure was destroyed by heating to $175^{\circ} \mathrm{C}$. Monostrontium aluminate hydrate was obtained by analogous methods in the form of minute needles or prisms with mean index 1.478. The maximum degree of hydration was not successfully determined, as the compound underwent decomposition to $3 \mathrm{SrO} \cdot \mathrm{Al}_{2} \mathrm{O}_{3} \cdot 6 \mathrm{H}_{2} \mathrm{O}$ and gibbsite. X-ray diffraction powder patterns indicate a close similarity in structure between the monocalcium and monostrontium aluminate hydrates.
\end{abstract}

\section{Introduction}

The existence of a monocalcium aluminate hydrate has been, for many years, a matter of some uncertainty among investigators in the field of cement hydration. Over 20 years ago, Assarsson [1] ${ }^{1}$ reported the preparation of a compound having the composition $\mathrm{CaO} \cdot \mathrm{Al}_{2} \mathrm{O}_{3} \cdot 10 \mathrm{H}_{2} \mathrm{O}$. It was obtained in the form of a "gel" by the action of water on anhydrous calcium aluminates and aluminous cements. Although Assarsson gave an X-ray diffraction powder pattern for the material, this in itself was not conclusive evidence of the existence of a monocalcium aluminate hydrate. A number of other hydrated calcium aluminates give somewhat similar patterns, and the gel might conceivably have been a mixture of two or more phases.

More recently, Longuet [2] reported the preparation of a compound for which he indicated the formula $\mathrm{CaO} \cdot \mathrm{Al}_{2} \mathrm{O}_{3} \cdot 7 \mathrm{H}_{2} \mathrm{O}$ as most probable. He also gave an X-ray diffraction pattern, differing in several respects from that given by Assarsson.

It has been pointed out in a previous paper [3] that the two patterns probably can be reconciled; also, that patterns agreeing in general with that of Longuet have been obtained at the Bureau on hydrated pastes of aluminous cements and of monocalcium aluminate. Because of the probable importance of this compound in the setting and hardening of aluminous cements, some additional work was undertaken in an attempt to obtain the hydrate in better crystallized form.

While this study was in progress, two additional important investigations bearing on the subject were reported in the literature. In the revised edition of "The Chemistry of Cement and Concrete" [4], Lea gives an X-ray diffraction pattern obtained by H. G. Midgley for $\mathrm{CaO} \cdot \mathrm{Al}_{2} \mathrm{O}_{3} \cdot 10 \mathrm{H}_{2} \mathrm{O}$. The pattern agrees fairly well with the more abbreviated patterns given by both Assarsson and Longuet. Farran [5] developed a novel technique for the study of crystal formation at the interface between cement

\footnotetext{
Figures in brackets indicate the literature references at the end of this paper.
}

and aggregate, and by this means obtained crystals of a monocalcium aluminate hydrate large enough for a determination of optical properties and shape. The crystals grew from a paste of aluminous cement, and the hydration product contained small amounts of one or more other phases. Farran also published an X-ray pattern for his preparation.

The existence of a monocalcium aluminate hydrate thus seems established. Because of the close relationship between calcium and strontium, it was considered of interest to determine whether a monostrontium aluminate hydrate also can be prepared.

\section{Apparatus and Procedure}

From the work of Assarsson [1] it appeared likely that formation of the monocalcium aluminate hydrate would be favored by low temperature; consequently, in the present study, most of the reaction mixtures were held near the freezing point. A household refrigerator, equipped with a special control unit and a blower, was used as a cold cabinet. The temperature ranged between $0^{\circ}$ and $2^{\circ} \mathrm{C}$.

Supersaturated solutions were prepared by shaking synthetic anhydrous monocalcium aluminate with water, filtering, and diluting the filtrate with distilled water or lime water as required. The solutions were kept in polyethylene bottles. A similar procedure was used in the study of the strontium analog.

The solutions were allowed to stand in the cold cabinet until precipitation was essentially complete, which in one case required several months. The precipitate was then separated by filtration with the aid of an aspirator and a suction train to minimize contamination by atmospheric carbon dioxide. Washing was omitted, because the solutions were extremely dilute, and the resulting contamination was negligible.

In addition to the experiments based on precipitation from supersaturated solutions, a few were conducted with pastes made from the anhydrous aluminates with small amounts of water. 


\section{Results and Discussion}

\subsection{Monocalcium Aluminate Hydrate}

Data pertaining to three preparations of monocalcium aluminate hydrate are given in table 1 . The precipitate in No. 1 was so finely divided that it formed a flocculent suspension that failed to settle out completely. Under the light microscope it appeared amorphous, but its crystalline character was revealed by the electron microscope, as well as by $\mathrm{X}$-ray diffraction. Figure 1 is an electron micrograph of this preparation. Other areas in the field showed some poorly defined matted fibers, possibly of amorphous hydrated alumina, and a very few hexagonal plates, much larger in size, were also noted. Neither of these phases is visible in figure 1. The X-ray diffraction pattern was similar to those reported by other investigators $[1,2,4,5]$ for monocalcium aluminate hydrate. No additional diffraction lines were observed.

The precipitate from solution 2 formed aggregates of fine crystals, which settled rather rapidly after the mixture was shaken. When first examined microscopically, 11 days after the reaction mixture was prepared, the precipitate was well formed. There was no visible change in it at 74 days, when it was filtered off. The crystals apparently were isotropic, with a refractive index about 1.47 . The index was observed to vary with the degree of drying. Under the electron microscope the preparation appeared to consist of aggregates of prismatic crystals, much larger than those of preparation 1. Some of the prisms showed terminal pyramids. A few hexagonal plates were also observed. The X-ray diffraction pattern was similar to that of the first preparation, but the intensities were stronger. A very weak line corresponding to the strongest reflection of $2 \mathrm{CaO} \cdot \mathrm{Al}_{2} \mathrm{O}_{3} \cdot 8 \mathrm{H}_{2} \mathrm{O}$ was also observed.

Preparation 3 was initially much more dilute than the others. Gibbsite was added to the solution, in the amount of $1 \mathrm{~g}$ for 1 liter, to hasten the precipitation, because it was supposed at the time that gibbsite would be the stable phase in this area. Precipitation was negligible during the first month, but after 6 months a new solid phase was observed, mixed with the gibbsite. It consisted of short hexagonal prisms with terminal pyramids (see fig. 2), occurring singly or in clusters. Also, in many cases, it appeared as a chainlike aggregate of crystals, which appeared to have grown around a long, slender needle. When viewed in contact with the solution in which they were grown, the prisms showed extremely low birefringence. The index of refraction of the prisms agreed with that of preparation 2, and the X-ray diffraction patterns showed that they were the same phase. The nature of the needles is unknown; they had the same index of refraction as the prisms, but showed slightly higher birefringence. A few of the needles may be observed in figure 2. The prismatic crystals are similar in appearance to those described by Farran, except that Farran's crystals are, in comparison, much shorter in the direction of the prism axis.

In addition to gibbsite and monocalcium aluminate hydrate, another phase was present in minor amount in preparation 3 . It consisted of large hexagonal plates, and was at first assumed to be $2 \mathrm{CaO} \cdot \mathrm{Al}_{2} \mathrm{O}_{3} \cdot 8 \mathrm{H}_{2} \mathrm{O}$. The $\mathrm{X}$-ray diffraction pattern, however, showed no trace of the dicalcium compound. It did contain three weak lines that could be attributed to tetracalcium aluminate hydrate, along with strong patterns of monocalcium aluminate hydrate and gibbsite. The appearance of tetracalcium aluminate in this region of the system, however, would be contrary to expectations based on earlier work at $21^{\circ} \mathrm{C}[6]$.

The molar oxide ratio, $\mathrm{CaO} / \mathrm{Al}_{2} \mathrm{O}_{3}$, in preparation 1 , determined by chemical analysis, was 1.04. In preparation 2 it was 1.01. Greater weight is attached to the latter value, because this preparation was microscopically almost homogeneous. The only observable impurity was dicalcium aluminate hydrate, present in amount estimated at less than 5 percent. Preparation 3 was not analyzed, as there were three solid phases present; also, the amount of material available was very small. Additional gibbsite may have been precipitated (as was originally expected), in which case it would be indistinguishable from that initially added. Hence, the oxide ratio 0.57 , calculated from the change in concentration of the solution, does not even approximately represent the composition of any one solid phase.

Accepting the oxide ratio as 1 to 1 , there remains the question of the amount of water of hydration.

TABLE 1. Data pertaining to preparation of $\mathrm{CaO} \cdot \mathrm{Al}_{2} \mathrm{O}_{3} \cdot 10 \mathrm{H}_{2} \mathrm{O}$ from calcium aluminate solutions at approximately $1^{\circ} \mathrm{C}$

\begin{tabular}{|c|c|c|c|c|c|c|c|c|}
\hline \multirow{2}{*}{$\begin{array}{l}\text { Prepa- } \\
\text { ration }\end{array}$} & \multicolumn{2}{|c|}{$\begin{array}{l}\text { Initial concentration } \\
\text { of solution }\end{array}$} & \multirow{2}{*}{$\begin{array}{l}\text { Duration } \\
\text { of storage }\end{array}$} & \multirow{2}{*}{ Solid phases present at end of storage } & \multicolumn{2}{|c|}{$\begin{array}{l}\text { Final concentration of } \\
\text { solution }\end{array}$} & \multirow{2}{*}{$\begin{array}{c}\text { Molar } \\
\text { ratio in } \\
\text { precipitate } \\
\mathrm{CaO} / \mathrm{Al}_{2} \mathrm{O}_{3}\end{array}$} & \multirow{2}{*}{ Appearance of precipitate } \\
\hline & $\mathrm{CaO}$ & $\mathrm{Al}_{2} \mathrm{O}_{3}$ & & & $\mathrm{CaO}$ & $\mathrm{Al}_{2} \mathrm{O}_{3}$ & & \\
\hline & g/liter & g/liter & Days & {$\left[\mathrm{CaO} \cdot \mathrm{Al}_{2} \mathrm{O}_{3} \cdot 10 \mathrm{H}_{2} \mathrm{O}\right.$; very few hexag- } & g/liter & g/liter & & \\
\hline & 0.833 & 1. 278 & 34 & $\left\{\begin{array}{l}\text { onal plates; probably some amor- } \\
\text { phous hydrated } \mathrm{Al}_{2} \mathrm{O}_{3} \text {. }\end{array}\right.$ & 0.198 & 0.148 & 1.04 & Gelatinous. \\
\hline $2 \ldots$ & .879 & 1.150 & 74 & $\left\{\begin{array}{l}\mathrm{CaO} \cdot \mathrm{Al}_{2} \mathrm{O}_{3} \cdot 10 \mathrm{H}_{2} \mathrm{O} ; \text { trace of } \\
2 \mathrm{CaO} \cdot \mathrm{Al}_{2} \mathrm{O}_{3} \cdot 8 \mathrm{H}_{2} \mathrm{O}\end{array}\right.$ & .300 & .104 & 1. 01 & $\{$ Finely crystalline aggregates. \\
\hline $3 \mathrm{a}_{-}$ & .327 & 0.466 & 210 & $\left\{\begin{array}{c}\text { Gibbsite; } \mathrm{CaO} \cdot \mathrm{Al}_{2} \mathrm{O}_{3} \cdot 10 \mathrm{H}_{2} \mathrm{O} ; \text { hexag- } \\
\text { onal plates in minor amount. }\end{array}\right.$ & .229 & .152 & $0.57 \mathrm{~b}$ & $\{$ Aggregates and separate crystals. \\
\hline
\end{tabular}

a Gibbsite added (1 $\mathrm{g}$ in 1 liter).

b Calculated from change in concentration of the solution. 


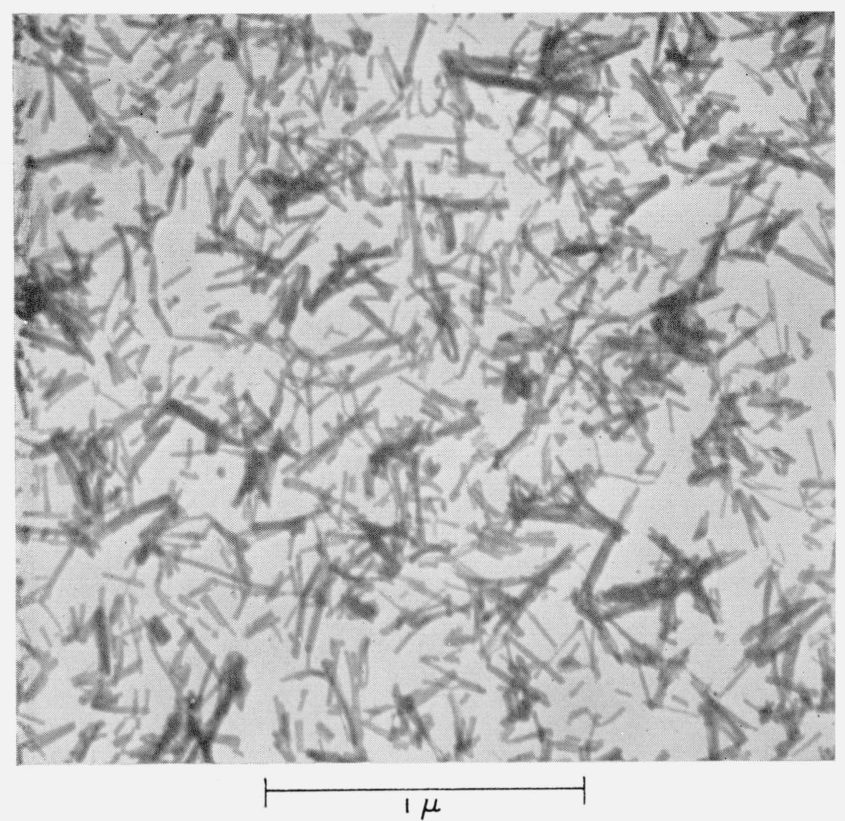

Figure 1. Electron micrograph of monocalcium aluminate hydrate (preparation 1 )

Magnification 32,500 diameters.

Assarsson [1] concluded from his analyses that the hvdrate contained 10 molecules of water. Longuet [2] reported approximately 7 molecules of water in his preparations after drying at 45 -percent relative humidity.

In the present study, preparation 2, after standing in a desiccator over $\mathrm{CaCl}_{2}$ for 3 months, had an ignition loss equivalent to 7.13 moles of $\mathrm{H}_{2} \mathrm{O}$ per mole of $\mathrm{Al}_{2} \mathrm{O}_{3}$. When placed over a saturated solution of $\mathrm{CaSO}_{4}$ at room temperature (relative humidity assumed to be $98 \%$ ) it rapidly took up water until the ratio of $\mathrm{H}_{2} \mathrm{O}$ to $\mathrm{Al}_{2} \mathrm{O}_{3}$ reached 9.9 at the end of 2 days, remaining essentially constant thereafter. A similar preparation confined over saturated $\mathrm{NH}_{4} \mathrm{Cl}$ (relative humidity about $79 \%$ ) attained a ratio $\mathrm{H}_{2} \mathrm{O} / \mathrm{Al}_{2} \mathrm{O}_{3}=9.8$. The results of these experiments strongly suggest that the fully hydrated compound has the composition $\mathrm{CaO} \cdot \mathrm{Al}_{2} \mathrm{O}_{3} \cdot 10 \mathrm{H}_{2} \mathrm{O}$. (This formula, though not definitely established, is used in this report to designate the compound.)

Three of the molecules of water apparently are very loosely bound, as they can be removed by drving over $\mathrm{CaCl}_{2}$.

Monocalcium aluminate hydrate was also prepared by mixing anhydrous monocalcium aluminate with a little water and storing the paste in the cold cabinet for 10 days. The X-ray diffraction pattern indicated the presence of $\mathrm{CaO} \cdot \mathrm{Al}_{2} \mathrm{O}_{3} \cdot 10 \mathrm{H}_{2} \mathrm{O}$, with smaller amounts of $2 \mathrm{CaO} \cdot \mathrm{Al}_{2} \mathrm{O}_{3} \cdot 8 \mathrm{H}_{2} \mathrm{O}$ and unhydrated $\mathrm{CaO} \cdot \mathrm{Al}_{2} \mathrm{O}_{3}$. Under similar conditions, a white aluminous cement, consisting essentially of $\mathrm{Al}_{2} \mathrm{O}_{3}$ and $\mathrm{CaO}$, likewise, was partially hydrated to monocalcium aluminate hydrate.

It has been shown that monocalcium aluminate hydrate may be prepared at approximately $1^{\circ} \mathrm{C}$.

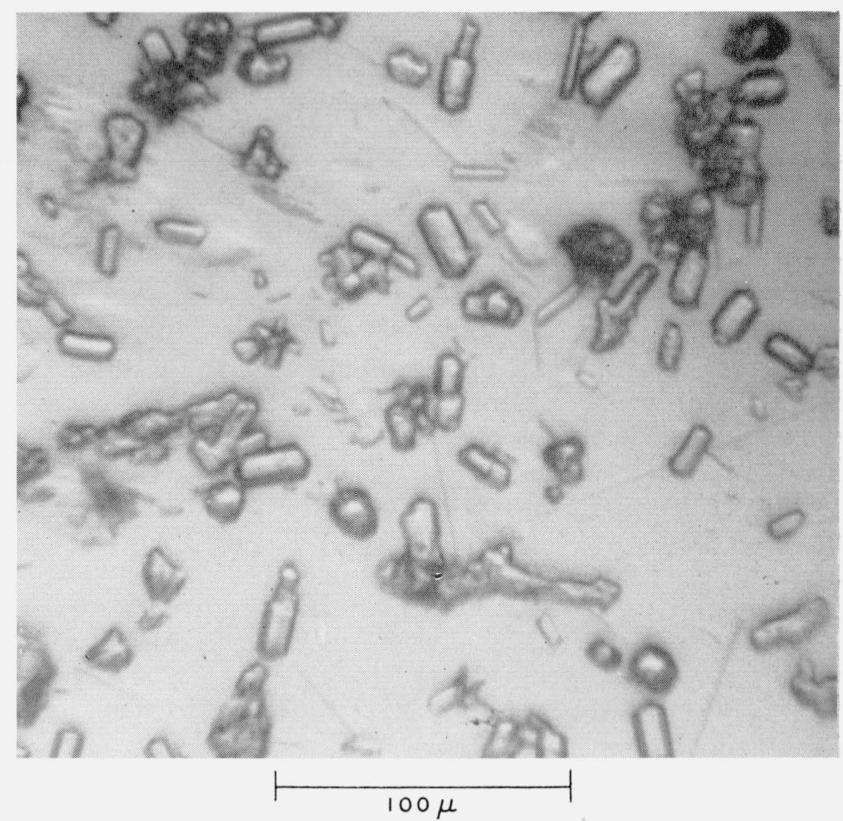

Figure 2. Photomicrograph of monocalcium aluminate hydrate (preparation 3$)$.

Magnification 300 diameters.

There is evidence that it may also form at slightly higher temperatures. Farran's preparations were made at $15^{\circ} \mathrm{C}$, whereas Midgley (as reported by Lea [4]) obtained $\mathrm{CaO} \cdot \mathrm{Al}_{2} \mathrm{O}_{3} \cdot 10 \mathrm{H}_{2} \mathrm{O}$ at $1^{\circ}$ and $20^{\circ} \mathrm{C}$, but not at $25^{\circ} \mathrm{C}$. In the present study, a few experiments with pastes led to the formation of monocalcium aluminate hydrate at $25^{\circ} \mathrm{C}$. Thus, when monocalcium aluminate paste was hydrated at $25^{\circ} \mathrm{C}$ for 10 days, the $\mathrm{X}$-ray diffraction pattern indicated the presence of monocalcium aluminate hydrate, together with a somewhat greater amount of dicalcium aluminate hydrate. As reported in a previous paper [3], similar experiments with the pastes of three aluminous cements at $24^{\circ} \mathrm{C}$ also gave evidence of the formation of monocalcium aluminate hydrate. These experiments have since been extended to include a white aluminous cement, known to consist largely of monocalcium aluminate and corundum. On curing for 7 days at $25^{\circ} \mathrm{C}$, the cement was partly hydrated to $\mathrm{CaO} \cdot \mathrm{Al}_{2} \mathrm{O}_{3} \cdot 10 \mathrm{H}_{2} \mathrm{O}$ and a smaller amount of $2 \mathrm{CaO} \cdot \mathrm{Al}_{2} \mathrm{O}_{3} \cdot 8 \mathrm{H}_{2} \mathrm{O}$.

From the foregoing discussion, it is evident that monocalcium aluminate hydrate can be formed at temperatures as high as $25^{\circ} \mathrm{C}$. In view of this fact, it is rather surprising that Wells, Clarke, and McMurdie [6], in their study of the system $\mathrm{CaO}-\mathrm{Al}_{2} \mathrm{O}_{3}-\mathrm{H}_{2} \mathrm{O}$ at $21^{\circ} \mathrm{C}$, failed to observe any such compound. Perhaps the explanation may be found in the difference in experimental conditions. The experiments of Wells et al. were performed not with pastes but with relatively large volumes of solutions.

There is evidence that in some earlier work of Wells [7], monocalcium aluminate hydrate was obtained at least once by precipitation from solution 
at room temperature. The actual temperature, unfortunately, was not recorded. The solution was an aqueous extract of an aluminous cement. The crystals obtained were well formed and similar in appearance to those shown in figure 2. Another precipitated phase (presumably hydrated alumina) was also present; hence the composition of the crystals could not be determined. The following optical properties were recorded: $\omega=1.477 ; \epsilon=1.492$; uniaxial positive. Apparently the phase was not observed again, although the study [3] included a large number of similar experiments. It is reasonable to assume, however, that the unknown crystals found by Wells were $\mathrm{CaO} \cdot \mathrm{Al}_{2} \mathrm{O}_{3} \cdot 10 \mathrm{H}_{2} \mathrm{O}$.

The completely hydrated crystals obtained in the present study had a refractive index of 1.471 , with birefringence too faint to measure. After the crystals had been dried to a water content equivalent to $\mathrm{CaO} \cdot \mathrm{Al}_{2} \mathrm{O}_{3} \cdot 7 \mathrm{H}_{2} \mathrm{O}$, the birefringence was stronger, and the minimum and maximum indices were 1.477 and 1.480. The birefringence is still much lower than that reported by Wells for the crystals described in the preceding paragraph. No explanation for the discrepancy can be offered, because the degree of drying of Wells' crystals is unknown. Farran [5] reported the indices, $\omega=1.489 \pm 0.002, \quad \epsilon=1.507$ \pm 0.002 , but here again the amount of preliminary drying was not stated.

Although the optical properties of the monocalcium aluminate hydrate were measurably affected by the degree of drying, no significant change was observed in the X-ray diffraction pattern. The pattern given in table 2 is for the material rehydrated to the decahydrate stage. The pattern for the material dried to the heptahydrate stage showed lines agreeing closely with those in the table, with no apparent trend in either direction. The pattern in table 2 is in excellent agreement with that obtained by Midgley, as reported by Lea [4]. The difference between corresponding $d$-spacings does not exceed $0.02 \mathrm{~A}$, except for the first line, for which the measurement error is necessarily high. Also, a few lines are reported as doublets in one pattern and as singlets in the other; and a very few weak lines are present in one pattern and not in the other. Good general correlation is also observed between these patterns and those of Assarsson [1], Longuet [2], and Farran [5], if allowance is made for the lines due to other phases present. Nevertheless, a few discrepancies are worthy of mention. The pattern given by Assarsson fails to show a spacing near $14 \mathrm{~A}$, although the patterns reported by the other investigators show a strong line in this region. Limitations of the earlier X-ray equipment may account for this difference. 'The largest spacing reported by Assarsson was $7.68 \mathrm{~A}$, whereas the line closest to this in the other patterns ranges in position from 7.16 to $7.3 \mathrm{~A}$. No explanation for this discrepancy can be advanced at present. In other respects, the pattern of Assarsson agrees well with that given in table 2. Farran's pattern is likewise in agreement, except that a few of the weaker lines are absent. Longuet's pattern shows the same series of lines, but for some reason they are all displaced toward higher $d$-spacings in comparison with the other patterns.
TABLE 2. X-ray powder diffraction patterns of $\mathrm{CaO} \cdot \mathrm{Al}_{2} \mathrm{O}_{3} \cdot 10 \mathrm{H}_{2} \mathrm{O}$ and $\mathrm{SrO} \cdot \mathrm{Al}_{2} \mathrm{O}_{3} \cdot n \mathrm{H}_{2} \mathrm{O}^{\text {a }}$

\begin{tabular}{|c|c|c|c|c|c|c|c|}
\hline \multicolumn{2}{|c|}{$\mathrm{CaO} \cdot \mathrm{Al}_{2} \mathrm{O}_{3} \cdot 10 \mathrm{H}_{2} \mathrm{O}$} & \multicolumn{2}{|c|}{$\mathrm{SrO} \cdot \mathrm{Al}_{2} \mathrm{O}_{3} \cdot n \mathrm{H}_{2} \mathrm{Ob}$} & \multicolumn{2}{|c|}{$\mathrm{CaO} \cdot \mathrm{Al}_{2} \mathrm{O}_{2} \cdot 10 \mathrm{H}_{2} \mathrm{O}$} & \multicolumn{2}{|c|}{$\mathrm{SrO} \cdot \mathrm{Al}_{2} \mathrm{O}_{3} \cdot n \mathrm{H}_{2} \mathrm{O}^{\mathrm{b}}$} \\
\hline$d$ & $I^{\mathrm{e}}$ & $d$ & $I$ & $d$ & $I^{c}$ & $d$ & $I$ \\
\hline $\begin{array}{c}A \\
14.2 \\
7.16 \\
5.37 \\
4.73 \\
4.51\end{array}$ & $\begin{array}{r}90 \\
100 \\
8 \\
10 \\
4\end{array}$ & $\begin{array}{c}A \\
14.7 \\
7.27 \\
5.43 \\
4.86 \\
4.61\end{array}$ & $\begin{array}{r}100 \\
95 \\
9 \\
28 \\
8\end{array}$ & $\begin{array}{c}A \\
2.18 \\
2.17 \\
2.11 \\
2.07 \\
2.03\end{array}$ & $\begin{array}{l}7 \\
7 \\
7 \\
5 \\
1\end{array}$ & $\begin{array}{c}A \\
2.22 \\
2.14 \\
2.11 \\
-\end{array}$ & $\begin{array}{c}29 \\
-20 \\
23 \\
\cdots\end{array}$ \\
\hline $\begin{array}{l}\text { 4. } 16 \\
\text { 3. } 96 \\
\text { 3. } 70 \\
\text { 3. } 56 \\
\text { 3. } 26\end{array}$ & $\begin{array}{r}4 \\
2 \\
7 \\
13 \\
7\end{array}$ & $\begin{array}{l}4.23 \\
4.04 \\
3.74 \\
3.65 \\
3.35\end{array}$ & $\begin{array}{r}6 \\
5 \\
15 \\
90 \\
33\end{array}$ & $\begin{array}{l}1.969 \\
1.945 \\
1.927 \\
1.879 \\
1.836\end{array}$ & $\begin{array}{l}2 \\
6 \\
1 \\
2 \\
3\end{array}$ & \begin{tabular}{c}
2.02 \\
1.97 \\
\hdashline 1.91 \\
1.88
\end{tabular} & $\begin{array}{c}23 \\
21 \\
-10 \\
15\end{array}$ \\
\hline $\begin{array}{l}3.10 \\
3.03 \\
2.91 \\
2.86 \\
2.70\end{array}$ & $\begin{array}{l}6 \\
2 \\
7 \\
8 \\
5\end{array}$ & \begin{tabular}{c}
3.14 \\
\hdashline 2.98 \\
2.91 \\
2.75
\end{tabular} & $\begin{array}{c}15 \\
-45 \\
31 \\
20\end{array}$ & $\begin{array}{l}1.786 \\
1.757 \\
1.713 \\
1.698 \\
1.650\end{array}$ & $\begin{array}{l}3 \\
2 \\
2 \\
1 \\
3\end{array}$ & $\begin{array}{c}1.84 \\
1.74 \\
1.68\end{array}$ & $\begin{array}{c}8 \\
-10 \\
-7\end{array}$ \\
\hline $\begin{array}{l}2.56 \\
2.48 \\
2.46 \\
2.37 \\
2.34\end{array}$ & $\begin{array}{r}11 \\
6 \\
6 \\
8 \\
6\end{array}$ & $\begin{array}{l}2.62 \\
2.53 \\
2.48 \\
2.43 \\
2.38\end{array}$ & $\begin{array}{r}52 \\
5 \\
8 \\
10 \\
14\end{array}$ & $\begin{array}{l}1.637 \\
1.630 \\
1.604 \\
1.555 \\
1.524\end{array}$ & $\begin{array}{l}1 \\
1 \\
4 \\
1 \\
1\end{array}$ & 1.64 & $\begin{array}{c}-\cdots \\
-\cdots \\
--- \\
-\cdots\end{array}$ \\
\hline $\begin{array}{l}2.30 \\
\text { 2. } 27\end{array}$ & $\begin{array}{r}1 \\
11\end{array}$ & $\begin{array}{l}2.33 \\
2.30\end{array}$ & $\begin{array}{l}15 \\
23\end{array}$ & $\begin{array}{l}1.472 \\
1.388\end{array}$ & $\begin{array}{l}1 \\
3\end{array}$ & 1.42 & 6 \\
\hline
\end{tabular}

a Obtained on a Geiger-counter diffractometer, using copper $\mathrm{K} \alpha$ radiation. $\mathrm{b} n=8.4$ in sample used for determination of X-ray pattern. $n$ may range from 7 to 10 .

${ }^{\circ} d=$ interplanar spacing; $I=$ relative intensity.

\subsection{Monostrontium Aluminate Hydrate}

In an earlier paper [8] on the strontium aluminates, it was reported that only the cubic tristrontium aluminate hydrate was formed by the various methods employed in that study. However, none of the experiments had been conducted below room temperature. It was, therefore, considered of interest to carry out some additional reactions in the cold cabinet.

In one experiment, anhydrous monostrontium aluminate was prepared by heating a mixture of strontium carbonate and alumina at $1,460^{\circ} \mathrm{C}$, followed by fusion in an oxygen blast. A small amount of the material was ground and placed in a vial with just enough water to moisten it. It was then stored in the cold cabinet for 10 days. An X-ray pattern of the hardened mass showed a series of lines very similar to the pattern of monocalcium aluminate hydrate. Lines of unhydrated $\mathrm{SrO} \cdot \mathrm{Al}_{2} \mathrm{O}_{3}$ were also present.

In another experiment, the new hydrate was prepared by a precipitation method analogous to that used for the calcium aluminate hydrate. For this purpose, anhydrous monostrontium aluminate was first prepared by heating a mixture of the hydrated oxides at $1,400^{\circ} \mathrm{C}$. Combination was not complete, but further heating was avoided because increased crystal size would tend to lower the rate of solution. The product was ground, shaken with water, and filtered, and the filtrate was stored in a glass flask in the cold cabinet. The data relevant to two such experiments are given in table 3.

Because of the extreme fineness of the precipitate, the optical properties could not be accurately 
TABLE 3. Data pertaining to preparation of $\mathrm{SrO} \cdot \mathrm{Al}_{2} \mathrm{O}_{2} \cdot 10 \mathrm{H}_{3} \mathrm{O}$ from strontium aluminate solutions at approximately $1^{\circ} \mathrm{C}$

\begin{tabular}{|c|c|c|c|c|c|c|}
\hline \multirow{2}{*}{$\begin{array}{l}\text { Prepa- } \\
\text { ration }\end{array}$} & \multicolumn{2}{|c|}{$\begin{array}{l}\text { Initial concen- } \\
\text { tration of } \\
\text { solution }\end{array}$} & \multirow{2}{*}{$\begin{array}{l}\text { Dura- } \\
\text { tion } \\
\text { of } \\
\text { stor- } \\
\text { age }\end{array}$} & \multirow{2}{*}{$\begin{array}{l}\text { Solid phase } \\
\text { present at end } \\
\text { of storage }\end{array}$} & \multirow{2}{*}{$\begin{array}{l}\text { Molar } \\
\text { ratio } \\
\mathrm{SrO} / \\
\mathrm{A}_{2} \mathrm{O}_{3} \text { in } \\
\text { prepa- } \\
\text { ration }\end{array}$} & \multirow{2}{*}{$\begin{array}{l}\text { Appearance of } \\
\text { precipitate }\end{array}$} \\
\hline & $\mathrm{SrO}$ & $\mathrm{Al}_{2} \mathrm{O}_{3}$ & & & & \\
\hline $1 \ldots$ & $\begin{array}{c}\text { g/liter } \\
4.43 \\
6.92\end{array}$ & $\begin{array}{l}\text { g/liter } \\
2.62 \\
5.66\end{array}$ & $\begin{array}{c}\text { Days } \\
14 \\
2\end{array}$ & $\begin{array}{l}\mathrm{SrO} \cdot \mathrm{Al}_{2} \mathrm{O}_{3} \cdot 10 \mathrm{H}_{2} \mathrm{O} \\
\mathrm{SrO} \cdot \mathrm{Al}_{2} \mathrm{O}_{3} \cdot 10 \mathrm{H}_{2} \mathrm{O}\end{array}$ & $\begin{array}{l}1.00 \\
0.98\end{array}$ & $\begin{array}{l}\text { Needles. } \\
\text { Slender prisms } \\
\text { about } 3 \mu \\
\text { long. }\end{array}$ \\
\hline
\end{tabular}

determined. The crystals were acicular and slightly birefringent, with a mean index of refraction about 1.478 .

The water content was determined by methods similar to those used for the calcium compound After exposure to high humidity (over saturated $\mathrm{Ca}(\mathrm{OH})_{2}$ solution) at $1^{\circ} \mathrm{C}$, the $\mathrm{H}_{2} \mathrm{O} / \mathrm{Al}_{2} \mathrm{O}_{3}$ ratio was 9.9 , whereas in material dried over $\mathrm{CaCl}_{2}$ the ratio was 6.9. Thus, the strontium and the calcium compounds appear to be analogous in their response to humidity changes. However, it was found necessary to keep the strontium aluminate hydrate in the cold cabinet while exposing it to the higher humidity, because it decomposed at room temperature. The products of decomposition, identified by microscopic and $\mathrm{X}$-rav methods, were $3 \mathrm{SrO} \cdot \mathrm{Al}_{2} \mathrm{O}_{3} \cdot 6 \mathrm{H}_{2} \mathrm{O}$ and gibbsite $\left(\mathrm{Al}_{2} \mathrm{O}_{3} \cdot 3 \mathrm{H}_{2} \mathrm{O}\right)$.

The $\mathrm{X}$-ray pattern given for the strontium aluminate hydrate in table 2 was obtained on a portion of preparation 1, which had been dried to a water content of about 8.4 moles per mole of $\mathrm{SrO} \cdot \mathrm{Al}_{2} \mathrm{O}_{3}$. Because of the acicular habit of the crystals, the relative intensities indicated may be somewhat affected by orientation. The similarity between the patterns of the strontium and calcium aluminate hydrates is readily apparent.

The question may be asked whether barium might also form a monoaluminate hydrate analogous to those of calcium and strontium. In an earlier paper [9] a barium aluminate hydrate, $\mathrm{BaO} \cdot \mathrm{Al}_{2} \mathrm{O}_{3} \cdot 7 \mathrm{H}_{2} \mathrm{O}$, was described. The amount of water of hydration is the same as that of the monocalcium and monostrontium aluminate hydrates dried over $\mathrm{CaCl}_{2}$. However, the barium compound differs from those of calcium and strontium in crystal habit, indices of refraction, and birefringence, and gives a distinctly different X-ray pattern. It seems clear, therefore, that $\mathrm{BaO} \cdot \mathrm{Al}_{2} \mathrm{O}_{3} \cdot 7 \mathrm{H}_{2} \mathrm{O}$ is not an analog of the monocalcium and monostrontium aluminate hydrates.

\section{Summary}

Monocalcium aluminate hydrate, probably having the composition $\mathrm{CaO} \cdot \mathrm{Al}_{2} \mathrm{O}_{3} \cdot 10 \mathrm{H}_{2} \mathrm{O}$, was prepared by precipitation from calcium aluminate solutions at approximately $1^{\circ} \mathrm{C}$, and by hydration of pastes of monocalcium aluminate and of aluminous cement at $1^{\circ}$ and $25^{\circ} \mathrm{C}$. Under conditions favorable for slow crystal growth, this hydrate crystallized as hexagonal prisms with terminal pyramids. They were very weakly birefringent, with a mean refractive index of 1.471. Drying over calcium chloride reduced the water of hydration to $7 \mathrm{H}_{2} \mathrm{O}$, and the indices and birefringence increased, but the X-ray pattern was apparently unchanged.

An analogous monostrontium aluminate hydrate was prepared by similar methods, but it was obtained only as minute needles or prisms. Like the calcium analog, it probably crystallizes with 10 molecules of $\mathrm{H}_{2} \mathrm{O}, 3$ of which may be removed by drying over calcium chloride. The mean index of refraction is about 1.478. When placed in a humid atmosphere at room temperature it decomposed, with the formation of $3 \mathrm{SrO} \cdot \mathrm{Al}_{2} \mathrm{O}_{3} \cdot 6 \mathrm{H}_{2} \mathrm{O}$ and $\mathrm{Al}_{2} \mathrm{O}_{3} \cdot 3 \mathrm{H}_{2} \mathrm{O}$ (gibbsite).

$\mathrm{X}$-ray powder diffraction patterns are given for both monocalcium aluminate hydrate and monostrontium aluminate hydrate. The similarity between the two is readily apparent.

The author acknowledges with thanks the assistance of several members of the Constitution and Microstructure Section of the Bureau, who prepared the X-ray diffraction patterns and the electron and photomicrographs.

\section{References}

[1] G. Assarsson, Sveriges Geol. Undersokn. 27 Ser. C, No. $379,22(1933)$

[2] P. Longuet, Symposium Chem. Cements, p. 328 (London, 1952 )

[3] L. S. Wells and E. T. Carlson, J. Research NBS 5\%, 335 (1956) RP2723.

[4] F. M. Lea, The chemistry of cement and concrete, ch. IX and appendix III (St. Martin's Press, Inc., New York, N. Y. 1956).

[5] J. Farran, Rev. matériaux construction et trav. publ., C. No. 490-491, 155; No. 492, 191 (1956).

[6] L. S. Wells, W. F. Clarke and H. F. MeMurdie, J. Research NBS 30, 367 (1943) RP1539.

[7] L. S. Wells (unpublished data, 1929).

[8] E. T. Carlson, J. Research NBS 54, 329 (1955) RP2595.

[9] E. T. Carlson and L. S. Wells, J. Research NBS 41, 103 (1948) RP1908.

Washington, January 31, 1957. 